\title{
Evaluation of New Herbicides on Weed Flora and Productivity of Chickpea (Cicer arietinum L.)
}

\author{
A.K. Gore*, A.S. Chavan, D.N. Gokhale and K.M. Thombre \\ Department of Agronomy, Vasantrao Naik Marathwada Agricultural University, \\ Parbhani-431 402, Maharashtra, India \\ *Corresponding author
}

\section{A B S T R A C T}

\begin{tabular}{|c|c|}
\hline & asons of $2013-14$ \\
\hline & $\begin{array}{l}0.75 \mathrm{~kg} / \mathrm{ha}(\mathrm{PE}), \mathrm{T}_{2:} \text { Trifluralin @ } 1.0 \mathrm{~kg} / \mathrm{ha}(\mathrm{PE}), \mathrm{T}_{3} \text { : Metolachlor } 0.75 \mathrm{~kg} / \mathrm{ha}(\mathrm{PE}), \mathrm{T}_{4} \\
\text { Imazethapyr @ } 0.75 \mathrm{~kg} / \mathrm{ha}(\mathrm{POE}), \mathrm{T}_{5} \text { : Quizalofop ethyl @ } 40 \mathrm{~g} / \mathrm{ha}(\mathrm{POE}), \mathrm{T}_{6}\end{array}$ \\
\hline $\begin{array}{l}\text { Pendimethalin, } \\
\text { Chickpea, Weed } \\
\text { control efficiency, } \\
\text { Weed management }\end{array}$ & $\begin{array}{l}\text { Propaquizafop @ } 0.75 \mathrm{~kg} / \text { ha }(\mathrm{POE}), \mathrm{T}_{7} \text { : Weed free and } \mathrm{T}_{8:} \text { Weedy check were evaluated } \\
\text { in randomized block design with three replications. The predominant weed flora were } \\
\text { Brachiria eruciformis, Chenopodium album, and Cynodon dactylon L. among monocost; } \\
\text { Cyperus rotundus L. among sedges; and Amaranthus viridis L., Digera arvensis, }\end{array}$ \\
\hline Article Info & Portulaca oleracea, Physalis minima, Euphorbia hirta, Parthenium hysterrophorus and \\
\hline $\begin{array}{l}\text { Accepted: } \\
26 \text { March } 2018 \\
\text { Available Online: } \\
10 \text { May } 2018\end{array}$ & $\begin{array}{l}\text { highest WCE, grain, bhoosa and biological yield was observed in Pendimethalin @ } 0.75 \\
\mathrm{~kg} \mathrm{ha}^{-1}(\mathrm{PE}) \text {, and it was significantly superior over rest of the treatments. Weedy check } \\
\text { recorded lowest grain and bhoosa yield. Among the chemical weed control treatments, The } \\
\text { application of Pendimethalin } 0.75 \mathrm{~kg} / \mathrm{ha}(\mathrm{PE}) \text { recorded beneficial higher grain, bhoosa }\end{array}$ \\
\hline & $\begin{array}{l}\text { yield, WCE, highest net monetary returns and B.C. ratio and it was found most economical } \\
\text { and effective in controlling weeds and increasing the yield of chickpea. }\end{array}$ \\
\hline
\end{tabular}

\section{Introduction}

Chickpea (Cicer arietinum L.) is most important pulse crop of India. It is most popular winter season pulse crop in several part of the country. In Maharashtra the area under chickpea was 12.54 lakh hectares with production of 9.78 lakh tonnes and average productivity of $780 \mathrm{~kg} \mathrm{ha}^{-1}$ (Anon., 2015-16). Weed management is one of the important factors, which cause marked effect on the growth and yield of chickpea. Further, with ever increasing use of fertilizer and irrigation water, weed management has assumed significant importance in modern intensive farming, as the total loss of crop yield with increasing cost of cultivation causes a greater economic loss to farmers. The magnitude of loss due to weeds largely depends upon the composition of weed flora, period of cropweed competition and its intensity. Uncontrolled weeds reduced seed yield of chickpea by 33 per cent (Tripathi and Vivek, 1995). Traditional methods of weed control could not be performed in time due to unavailability of labour and higher cost. Under 
these situations, use of herbicides in this crop can be a visible and effective option of weed control. There are various new herbicides which are available in market for effective weed management and control of weeds. It is necessary to evaluate these new herbicides for effective weed control in gram. Considering the above facts and views, the present experiment was undertaken to study the effect of weed management on chickpea production.

\section{Materials and Methods}

A field experiment was conducted during the two consecutive years of 2013-14 and 2014-15 at Experimental Research Farm of AICRP on Dry land Agriculture, VNMKV, Parbhani (Maharashtra) situated between 19 '60' N latitude, $76^{\circ}$ 47' $\mathrm{E}$ longitude and has an altitude of about $409 \mathrm{~m}$ above mean sea level and has a subtropical climate. The soil of the experimental field was clay in texture, having pH 7.65 and 7.68 in first and second year, respectively, low in available nitrogen (212, $215 \mathrm{~kg} / \mathrm{ha}$, in first and second year, respectively), medium in available phosphorus $(17,17 \mathrm{~kg} / \mathrm{ha}$, in first and second year, respectively) and fairly rich in available potassium $(544,565 \mathrm{~kg} / \mathrm{ha}$, in first and second year, respectively) with slightly alkaline reaction. The study involved eight treatment combinations consisting of $\mathrm{T}_{1}$ : Pendimethalin $0.75 \mathrm{~kg} / \mathrm{ha}(\mathrm{PE}), \mathrm{T}_{2:}$ Trifluralin $1.0 \mathrm{~kg} / \mathrm{ha}$ $(\mathrm{PE}), \mathrm{T}_{3}$ : Metolachlor $0.75 \mathrm{~kg} / \mathrm{ha}(\mathrm{PE}), \mathrm{T}_{4}$ : Imazethapyr $0.75 \mathrm{~kg} /$ ha $(\mathrm{POE}), \mathrm{T}_{5}$ : Quizalofop ethyl $40 \mathrm{~g} / \mathrm{ha}$ (POE), $\mathrm{T}_{6}$ : Propaquizafop $0.75 \mathrm{~kg} / \mathrm{ha}(\mathrm{POE}), \mathrm{T}_{7}$ : Weed free and $\mathrm{T}_{8}$ : Weedy check which were evaluated in randomized block design with three replications. The experimental plots were $5.4 \mathrm{~m}$ wide and $4.5 \mathrm{~m}$ long, laid out according to randomized block design with each treatment replicated thrice. Chickpea cv. 'Vijay' was used for sowing. The crop was fertilized with recommended dose of fertilizer (25:50:00 $\left.\mathrm{kg} \mathrm{N}: \mathrm{P}_{2} \mathrm{O}_{5}: \mathrm{K}_{2} \mathrm{O} \mathrm{kg} / \mathrm{ha}\right)$. Pre emergence and post emergence herbicides were applied using knapsack sprayer fitted with flat fan nozzle attached with the hood of sprayer by mixing in $500 \mathrm{~L}$ of water/ha as per treatment. Besides a light irrigation just after sowing, crop received three post sowing irrigations during all the two years of experimentation. Data on weed dry weight were recorded at 30,60,90 days after sowing and at harvest. The observations on weed density and their dry matter were taken randomly from $1.0 \mathrm{~m}^{2}$ quadrat from net plot area from each treatment. Same were harvested and then oven dried for 48 hours at $70^{\circ} \mathrm{C}$. Weed control efficiency (WCE) was calculated by using the following formula by Mani et al., (1973).

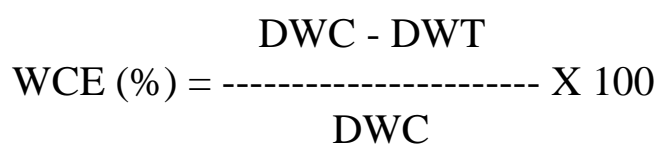

Where, DWC and DWT were the weed dry weight $\left(\mathrm{kg} \mathrm{ha}^{-1}\right)$ in control and treated plots, respectively. The data recorded were statistically analyzed using MSTATC Software. The purpose of analysis of variance was to determine the significant effect of treatments on weeds and chickpea. LSD test at $5 \%$ probability level was applied when analysis of variance showed significant effect for treatments (Steel and Torrie, 1980).

\section{Results and Discussion}

\section{Weed flora}

The prominent weed flora observed in the experiment was Brachiria mutica, Echinochloa crusgalli L. and Cynodon dactylon L. among monocots; Cyperus rotundus L. among sedges; and Amaranthus viridis L., Digera arvensis Physalis minima, Euphorbia hirta, Parthenium hysterophorus and Alternenthara sessili among dicot weeds during both the years of investigation. 
Table.1 Weed dry matter of monocot and dicot weeds as influenced by various treatments (Pooled data of 2 years)

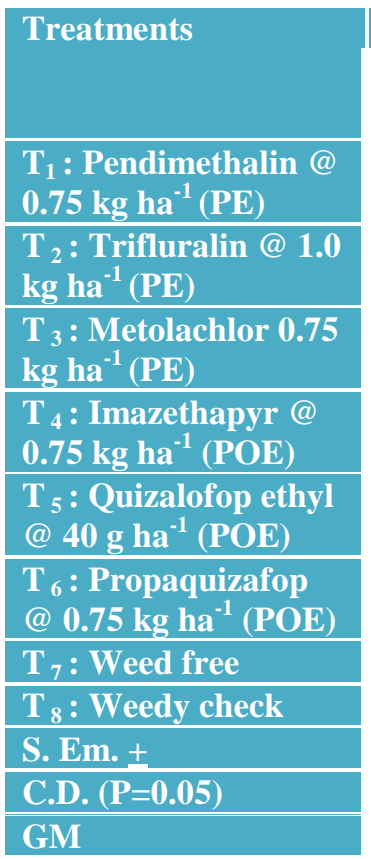

\begin{tabular}{|c|c|c|c|c|c|c|c|}
\hline Weed dry matter of monocot $(\mathrm{g})$ & \multicolumn{4}{|l|}{ Weed dry matter of dicot (g) } \\
\hline 30 DAS & 60 DAS & 90 DAS & $\begin{array}{l}\text { At } \\
\text { harvest }\end{array}$ & 30 DAS & 60 DAS & 90 DAS & $\begin{array}{l}\text { At } \\
\text { harvest }\end{array}$ \\
\hline 3.07 & 8.89 & 6.59 & 7.37 & 5.32 & 8.94 & 6.92 & 7.91 \\
\hline 3.31 & 9.73 & 7.27 & 8.66 & 6.15 & 11.91 & 9.96 & 9.21 \\
\hline 3.26 & 8.58 & 6.59 & 6.98 & 5.83 & 11.07 & 9.94 & 8.79 \\
\hline 3.04 & 8.31 & 6.26 & 6.69 & 5.59 & 11.27 & 9.10 & 8.62 \\
\hline 2.89 & 7.73 & 5.28 & 4.79 & 6.23 & 12.05 & 10.64 & 9.16 \\
\hline 2.94 & 7.93 & 5.60 & 5.44 & 6.44 & 12.66 & 12.19 & 11.96 \\
\hline 2.67 & 7.18 & 5.36 & 5.04 & 4.05 & 6.42 & 5.23 & 6.22 \\
\hline 5.31 & 8.96 & 7.90 & 14.69 & 12.53 & 24.06 & 21.86 & 21.36 \\
\hline 0.16 & 0.33 & 0.41 & 1.09 & 0.19 & 0.49 & 1.07 & 1.03 \\
\hline 0.48 & 0.99 & 1.23 & 3.27 & 0.57 & 1.47 & 3.21 & 3.09 \\
\hline 2.74 & 7.95 & 7.21 & 6.47 & 7.12 & 13.68 & 11.28 & 10.69 \\
\hline
\end{tabular}

Table.2 Weed control efficiency of monocot and dicot weeds as influenced by various (Pooled data of 2 years)

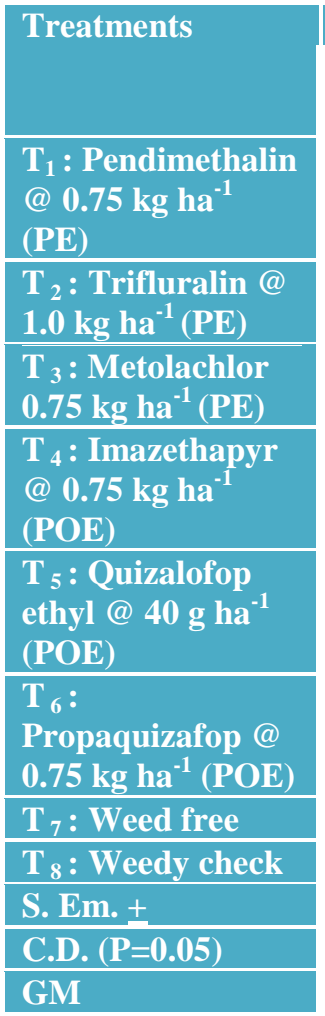

\begin{tabular}{|c|c|c|c|c|c|c|c|}
\hline Weed con & ol efficien & y of monoc & & Weed con & rol efficien & of dicot & \\
\hline 30 DAS & 60 DAS & 90 DAS & $\begin{array}{l}\text { At } \\
\text { harvest }\end{array}$ & $30 \mathrm{DAS}$ & 60 DAS & 90 DAS & $\begin{array}{l}\text { At } \\
\text { harvest }\end{array}$ \\
\hline 67.46 & 64.64 & 58.74 & 57.35 & 76.13 & 72.33 & 70.04 & 68.75 \\
\hline 66.09 & 63.82 & 54.78 & 58.46 & 69.80 & 66.46 & 63.06 & 60.88 \\
\hline 68.67 & 66.76 & 59.82 & 57.90 & 66.73 & 65.95 & 63.02 & 59.66 \\
\hline 68.56 & 67.80 & 62.76 & 60.14 & 73.98 & 70.09 & 67.02 & 66.77 \\
\hline 72.80 & 72.29 & 70.07 & 68.73 & 67.56 & 63.33 & 60.04 & 57.99 \\
\hline 73.42 & 72.72 & 69.35 & 67.54 & 66.55 & 61.72 & 59.00 & 56.88 \\
\hline 78.51 & 81.59 & 78.32 & 76.32 & 82.87 & 81.44 & 80.11 & 78.80 \\
\hline - & - & - & - & - & - & - & - \\
\hline 67.56 & 64.79 & 62.02 & 60.30 & 68.83 & 65.17 & 62.31 & 61.32 \\
\hline 65.81 & 59.8 & 57.67 & 56.03 & 74.68 & 70.16 & 69.89 & 67.6 \\
\hline 66.03 & 64.71 & 59.18 & 62.37 & 63.58 & 66.65 & 63.69 & 61.82 \\
\hline
\end{tabular}


Table.3 Yield attributes, grain yield (kg/ha) and $\mathrm{BC}$ ratio of chickpea as influenced by various treatments (pooled data of 2 years)

\begin{tabular}{|c|c|c|c|c|}
\hline Treatments & $\begin{array}{l}\text { No. of seeds per } \\
\text { pod }\end{array}$ & $\begin{array}{l}\text { No. of seeds per } \\
\text { pod }\end{array}$ & Grain yield (kg/ha) & B:C ratio \\
\hline $\begin{array}{l}T_{1} \text { : Pendimethalin } \\
@ 0.75 \mathrm{~kg} \mathrm{ha}^{-1}(\mathrm{PE}) \\
\end{array}$ & 1.84 & 94.25 & 2272 & 2.83 \\
\hline $\begin{array}{l}\mathrm{T}_{2} \text { : Trifluralin @ } \\
1.0 \mathrm{~kg} \mathrm{ha}^{-1}(\mathrm{PE})\end{array}$ & 1.00 & 62.90 & 1859 & 2.51 \\
\hline $\begin{array}{l}T_{3}: \text { Metolachlor } \\
0.75 \mathrm{~kg} \mathrm{ha}^{-1}(\mathrm{PE}) \\
\end{array}$ & 0.93 & 60.50 & 1802 & 2.20 \\
\hline $\begin{array}{l}T_{4}: \text { Imazethapyr } \\
\text { @ } 0.75 \mathrm{~kg} \mathrm{ha}^{-1} \\
\text { (POE) }\end{array}$ & 1.15 & 82.41 & 2192 & 2.50 \\
\hline $\begin{array}{l}\mathrm{T}_{5}: \text { Quizalofop } \\
\text { ethyl @ } 40 \mathrm{~g} \mathrm{ha}^{-1} \\
\text { (POE) }\end{array}$ & 1.13 & 79.30 & 2150 & 2.70 \\
\hline $\begin{array}{l}\text { T }_{6} \text { : Propaquizafop } \\
\text { @ } 0.75 \mathrm{~kg} \mathrm{ha}^{-1} \\
\text { (POE) }\end{array}$ & 1.04 & 68.26 & 2117 & 2.62 \\
\hline $\mathrm{T}_{7}:$ Weed free & 1.87 & 95.20 & 2369 & 2.39 \\
\hline $\mathrm{T}_{8}:$ Weedy check & 0.83 & 56.73 & 1524 & 2.00 \\
\hline S. Em. \pm & 2.24 & 77.57 & 77.57 & - \\
\hline C.D. $(P=0.05)$ & 6.72 & 189.9 & 189.9 & - \\
\hline GM & 1.22 & 74.94 & 2035 & 2.47 \\
\hline
\end{tabular}

\section{Effect on weeds}

Marked reduction in dry matter of weeds was observed in plot receiving pre-emergence application of pendimethalin $0.75 \mathrm{~kg} / \mathrm{ha}\left(\mathrm{T}_{1}\right)$ followed by application of Imazethapyr 0.75 $\mathrm{kg} / \mathrm{ha}(\mathrm{POE})\left(\mathrm{T}_{4}\right)$ and proved superior to other treatments. Weed control efficiency and weed index varied appreciably under various weed management practices. Both indices indicated the efficiency of weed control treatments.

Identical increase in weed control efficiency was noted with treatment weed free check through 20 days up to 80 days after sowing $\left(\mathrm{T}_{7}\right)$ followed by Pendimethalin $0.75 \mathrm{~kg} / \mathrm{ha}$ $\left(\mathrm{T}_{1}\right)$ and followed by Imazethapyr $0.75 \mathrm{~kg} / \mathrm{ha}$ (POE) $\left(\mathrm{T}_{4}\right)$, respectively. Contrary to this, the lowest weed index was observed with weed free check $\left(\mathrm{T}_{7}\right)$ followed by Pendimethalin $0.75 \mathrm{~kg} / \mathrm{ha}\left(\mathrm{T}_{1}\right)$ and followed by Imazethapyr $0.75 \mathrm{~kg} / \mathrm{ha}(\mathrm{POE})\left(\mathrm{T}_{4}\right)$. This is due to lower weed population and reduced dry matter production of weeds during initial stage and which ultimately provided weed free environment to chickpea crop in respective treatments. Similar findings are related with sharma et al., (2006) and Kacchadiya et al., (2009) (Table 1 and 2).

\section{Yield attributes and yield}

Weed free check proved its superiority by producing higher number of seeds per pod, weight of pods, and number of seeds per plant compared to other treatments. While, unwedded control $\left(\mathrm{T}_{8}\right)$ noted significantly lowest value of all the yield attributes. This might be due to least competition offered by weeds for nutrients and moisture at crucial growth stages under weed free treatment which ultimately improved all yield attributes besides increased rate of $\mathrm{N}, \mathrm{P}$ and $\mathrm{K}$ absorption cumulatively helped the crop plants to produce more surface area for high 
photosynthetic rate as well as maximum translocation of photosynthates from source to sink, subsequently resulted in improvement of all yield attributes. Because of synergist effect among the yield attributes, they benefited each other. These findings are in accordance with those of Singh et al., (2003) and Ratnam et al., (2011). Ultimately the pronouncing effect of all said growth parameter reflected on grain and bhusa yield and treatments weed free (Weeding at 20 days to up to 80 DAS) and pendimethalin $0.75 \mathrm{~kg} / \mathrm{ha}$ as preemergence were highest among all the treatments and were on par for grain yield (2476 and $2376 \mathrm{~kg} / \mathrm{ha}$, respectively during first year, 2261 and $2167 \mathrm{~kg} / \mathrm{ha}$ during second year, respectively) and bhoosa yield per hectare, respectively, and were significantly superior over rest of the weed management practices (Table 3 ).

The mean yield shows that significantly higher grain yield was observed in weed free treatment which was found at par with pendimethalin $0.75 \mathrm{~kg} / \mathrm{has}$ pre emergence application and significantly higher over the rest of treatments. Similar findings are related with Butter et al., (2008) and Kacchadiya et al., (2009).

\section{Economics}

From the economic point of view, data further revealed that maximum $\mathrm{BCR}$ of 2.35 and 2.43, during 2013-14 and 2014-15 respectively was realized in $\mathrm{T}_{7}$ (Weed free (HW at 20 days up to $80 \mathrm{DAS}$ ) followed by $\mathrm{T}_{1}$ (Pendimethalin $0.75 \mathrm{~kg} / \mathrm{ha}(\mathrm{PE})$ ) with $\mathrm{BCR}$ value of 2.81 and 2.86, respectively. The lowest BCR value of 2.02 and 1.99 was noted in treatment $\mathrm{T}_{8}$ (unweeded control), respectively. These findings are in accordance with those reported by Singh (2007), Rao et al., (2003) and Kacchadiya et al., (2009). Thus, high profitable grain yield of chickpea $\mathrm{Cv}$. Vijay can be obtained by sowing the crop either at $45 \mathrm{~cm} \mathrm{x} 10 \mathrm{~cm}$ and by applying pendimethalin $0.75 \mathrm{~kg} / \mathrm{ha}$ as pre-emergence or by applying imazethapyr $0.75 \mathrm{~kg} / \mathrm{ha}$ as post emergence application.

\section{References}

Anonymous (2015) Weed control in chickpea, Thesis submitted to VNMKV, Parbhani.

Butter GS, Aggarwal N. and Singh, S. (2008). Efficacy of different herbicides in chickpea. Indian Journal of Weed Science. 40 (3 \& 4):169-171.

Kachhadiya SP, Savaliya JJ, Bhalu VB, Pansuria AG and Savaliya SG (2009). Evaluation of new herbicides for weed management in chickpea. Legume Research an International Journal. 32(4):293-297.

Latha KR and Nadarajan N. (2009). Effect of pre and post-emergence herbicides in rainfed pigeonpea. National symposium on weed threat to environment, biodiversity and agriculture productivity. August 2-3, 2009. TNAU, Coimbatore.

Mani VS, Gautam KC and Chakraborthy (1973). Losses in crop yield due to weed growth. IlINS 14: 142-58

Rao MM, Ramalakshmi D, Khan MM, Sree SP and Reddy MV (2003). Effect of integrated weed management in post rainy season pigeonpea + mungbean intercropping system in vertisols. Indian Journal of Pulses Research, 16 (2):112115.

Ratnam M, Rao AS and Reddy TY (2011). Integrated weed management in chickpea. Indian Journal of Weed Science. 43 (1 \& 2):70-72.

Sharma KK, and Goswami VK (2006). Integrated weed management in chickpea. Indian Journal of Weed Science. 20 (2):102-103

Singh RS (2007). Integrated weed management in pigeonpea (Cajanus 
cajan). Environment and Ecology. 25S (Special 3A): 780-782.

Singh RV, Sharma AK and Tomar AKS (2003). Weed control in chickpea under late sown condition. Indian Journal of Agronomy. 48(2):114-116.

Steel R.G.D., and Torrie JH (1980). Priociples and procedures of statistics, 2nd
Edition, pp. 172-77. McGraw Hill Book Co., Singapore.

Tripathi SS and Vivek SS (1995). Evaluation of Dinitroniline herbicides for weed management in pigeonpea. Indian Journal of Weed Science, 27 (3-4):152153.

\section{How to cite this article:}

Gore, A.K., A.S. Chavan, D.N. Gokhale and Thombre, K.M. 2018. Evaluation of New Herbicides on Weed Flora and Productivity of Chickpea (Cicer arietinum L.). Int.J.Curr.Microbiol.App.Sci. 7(05): 3682-3687. doi: https://doi.org/10.20546/ijcmas.2018.705.425 